Pleione 12(1): 128 - 131. 2018.

ISSN: 0973-9467

(C) East Himalayan Society for Spermatophyte Taxonomy

doi:10.26679/Pleione.12.1.2018.128-131

\title{
A new record for the orchid flora of Darjeeling Himalaya of West Bengal: Gastrochilus affinis (King \& Pantl.) Schltr. (Orchidaceae)
}

\author{
Rajendra Yonzone \\ The Orchid Society of Eastern Himalaya, Purba Samalbong busty, P.O. Sinji, Dist: Kalimpong 734301, \\ West Bengal, India \\ E-mail: ryonzone99@gmail.com
}

[Received 06.05.2018; Revised \& accepted 27.06.2018; Published 30.06.2018]

\begin{abstract}
Gastrochilus affinis (King \& Pantl.) Schltr. (Orchidaceae) is reported as a new distributional records for the Darjeeling Himalaya of West Bengal, India. Detailed morphological features, phenology, updated nomenclature, current status and photographs of the taxon is provided.
\end{abstract}

Key words: Gastrochilus affinis, New record, Darjeeling Himalaya, West Bengal.

\section{INTRODUCTION}

The Darjeeling Himalayan region, forming a cap on the northen end of the state of West Bengal, is a storehouse for a large number of temperate and tropical Orchids. Most prominently, the region is rich in Orchid diversity and harbours about 311 species (Yonzone et al. 2012a). When considered from agro-floricultural point of view, the region is known throughout the world as botanical paradise. The presence of humus rich forest floor and moist microclimatic zones made the region ideal for the growth of several terrestrial orchids like species of Acanthephippium, Anoectochilus, Anthogonium, Calanthe, Cheirostylis, Crepidium, Galiola, Goodyera, Habenaria, Herminium, Herpysma, Nephelaphyllum, Nervilia, Odontochilus, Peristylus, Phaius, Platanthera, Tainia, Tipularia, Zeuxine etc. Altitudinally, the floristic stretch in Darjeeling Hills ranges from as low as $\pm 120 \mathrm{~m}$ amsl in the plains of Siliguri to as high as $3660 \mathrm{~m}$ amsl at Sandakphu. Due to great variation in altitude high atmospheric humidity, quick changes in aspects, wide range of climatic zones are available, which favour the abundant growth of diversified and prosperous vegetation (Das 2004; Yonzone 2017).

While working on Orchid Flora of Darjeeling Himalaya (2007 - 2017), the author came across some interesting specimens of epiphytic orchid species. After a thorough survey of literature (Bose et al. 1999; Lucksom 2007; Pearce \& Cribb 2002; Pradhan 1979), expert consultation, critical examination and comparison with other authenticated specimens, the identity of the plant has been confirmed as Gastrochilus affinis (King \& Pantl.) Schltr. A perusal of literature related to the Orchids of Darjeeling (Bose et al. 1999; Bruhl 1926; Hooker 1888 - 1890; Ohashi 1975; Pearce \& Cribb 2002; Pradhan 1979; Yonzone et al. 2011, 2012a,b; Yonzone 2015), revealed that the species was not recorded previously from the Darjeeling Himalaya and that is from the state of West Bengal. Therefore, the present collection of Gastrochilus affinis from the Darjeeling Himalaya forms the new record for Darjeeling Himalaya as well as for the state of West Bengal in India. However, earlier Das \& Chanda (1987) recorded four species of Gastrochilus [G.calceolaris (Sm.) D.Don; G.corymbosus AP. Das \& Chanda; G.dasypogon (Sm.) Kuntze; G.distichus (Lindl.) Kuntze] 


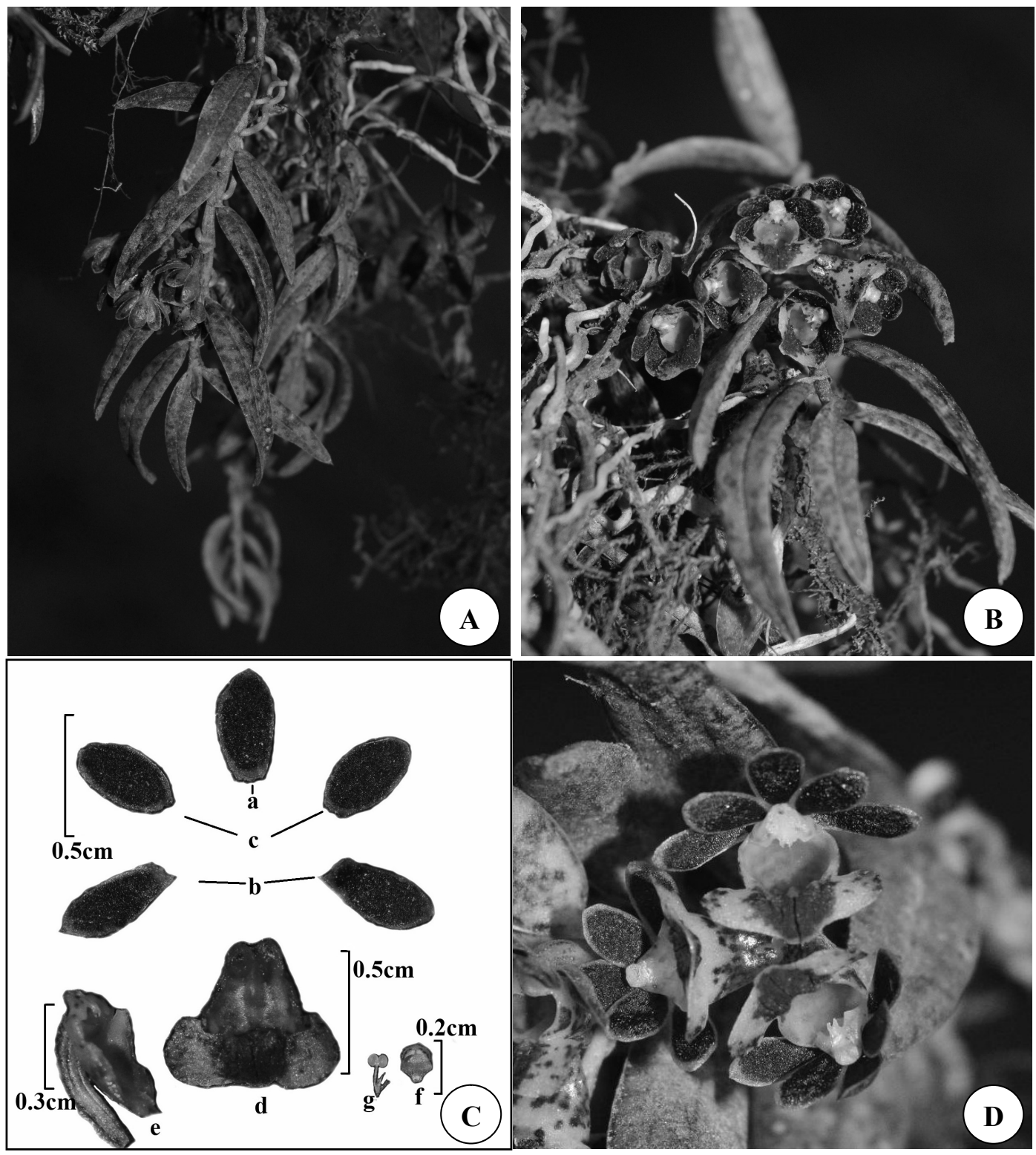

PLATE - I. Gastrochilus affinis (King \& Pantl.) Schltr., A. Plant in habita;, B. Close view of inflorescence; C. Display of floral parts: a. dorsal sepal, b. lateral sepals, c. petals, d. lip, e. pedicellate ovary, f. anther, g. Pollinia; D. Close up of flowers.

from the temperate hills of Darjeeling. The voucher specimen has been deposited in herbarium of Cluny Women's College, Kalimpong. A detailed taxonomic account of the species based on fresh specimens along with habitat, altitudinal range of distribution, current status, local distribution within Darjeeling and geographical distribution are provided in the present paper.

The generic name Gastrochilus is derived from the Greek words gastro (belly) and cheilos (lip). The genus Gastrochilus established in 1825 by David Don in his Prodromus Florae Nepalensis. It comprises about 20 species distributed in India, Nepal, South East Asia, Malaysia and the adjacent islands (Pearce \& Cribb 2002). 
Gastrochilus affinis (King \& Pantl.) Schltr., Feddes Repert, Spec. Now. Regni Veg. 12: 314. 1918; Saccolabium affine King \& Pantl., Ann. Roy. Bot. Gard. (Calcutta) 8: 228, t.30. 1898. [PLATE - I]

Plants epiphytic, $7-15 \mathrm{~cm}$ long. Stem sheathed. Leaves $8-15,2-2.6 \times 0.4-0.6 \mathrm{~cm}$, distichous, oblong-lanceolate to subspathulate, apex minutely 2 or 3 dentate, fleshy, sessile. Racemes, 2 - 4-flowered; floral bracts glabrous, slender. Flowers $0.6-0.8 \mathrm{~cm}$ across; sepals and petals green flushed with brown, lip yellowish. Dorsal sepal $0.3-0.5 \times 0.1-0.13$ $\mathrm{cm}$; lateral sepals $0.36-0.4 \times 0.08-0.13 \mathrm{~cm}$, ovate-elliptic, obtuseovate-elliptic, obtuse. Petals $0.3-0.4 \times 0.1-0.13 \mathrm{~cm}$, ovate-elliptic, obtuse; lip 3-lobed, $0.3-0.4 \times 0.2-0.3 \mathrm{~cm}$, adnate to the column base, saccate; side lobes narrow; apical lobe decurved, subacute; disk with 2 thick median ridges from base to apex.

Specimen examined: INDIA, West Bengal, Darjeeling Himalaya, District Darjeeling, Meghma 2770 ?? $\mathrm{m}$ (Border area of Nepal and India), Rajendra Yonzone 1464, dated 06.05.2017.

Flowering \& Fruiting: May - July.

Habitat \& Ecology: Epiphyte on tree trunk and branches.

Current Status: Threatened due to indiscriminate collection and habitat destruction by anthropogenic activities.

Note on distribution in India: Endemic to Sikkim (Pradhan 1979); Sikkim (Bose et al. 1999).

Altitudinal distribition: $2600 \mathrm{~m}$ (Pradhan 1979); $2500 \mathrm{~m}$ (Bose et al. 1999); 2600 - $3000 \mathrm{~m}$ (Pearce \& Cribb 2002).

Distribution within Darjeeling: Neora Valley - Kalimpong.

Geographical distribution: North East India.

\section{LITERATURE CITED}

Bose, T.K.; Bhattacharjee S.K.; Das, P. \& Basak U.C. 1999. Orchids of India. Revised Edition. Naya Prokash. Calcutta, India, pp. 461.

Bruhl, P. 1926. A Guide to the Orchids of Sikkim. Bishen Singh Mahendra Pal Singh, Dehradun, India.

Das, A.P. 1986. On the floristic and palynological surveys of Darjeeling and the adjoining places (vols. $1 \& 2$ ). Ph.D. Thesis. University of Calcutta.

Das, A.P. 2004. Floristic studies in Darjiling hills. Bull. Bot. Surv. India 43(1-4): $1-18$.

Das, A.P. \& Chanda, S. 1987. Flowering calendar of the angiospermic flora of Darjeeling Hills, West Bengal (India). Trans. Bose Res. Inst. 51(4): 99 - 133.

Hooker, J.D. 1888 - 1890. The Flora of British India. Vol. 5 \& 6. L. Reeve \& Co. London.

Lucksom, S.Z. 2007. The Orchids of Sikkim and North East Himalaya. Development Area, Jiwan Thing Marg, Gangtok, East Sikkim, India. pp. 839 and 854.

Ohashi, H. 1975. The Flora of Eastern Himalaya, Third Report. University of Tokyo press, Japan.

Pearce, N.R. \& Cribb, P.J. 2002. Flora of Bhutan. The Orchids of Bhutan. Vol. 3, part 3. Royal Botanic Garden, Edinburgh. pp. 577. 
Pradhan, U.C. 1979. Indian Orchids Guide to Identification and Culture, (Vol. II) Premulaceae Books, Kalimpong, India. pp. 567.

Yonzone, R.; Lama, D.; Bhujel, R.B. \& Rai, S. 2011. Epiphytic Orchid species Diversity of Darjeeling Himalaya of India. Asian J. Pharm. Life Sci. 1(4): 449 - 465.

Yonzone, R.; Bhujel, R.B.; Lama, D. \& Rai, S. 2012a. Orchid species Diversity of Darjeeling Himalaya of India. Intn. J. Pharm. Life Sci. 3(3): 1533 - 1550.

Yonzone, R.; Lama. D.; Bhujel, R.B.; Gogoi, K. \& Rai, S. 2012b. Taxonomic Assessment on the reported Orchid species of Darjeeling district from Flora of Bhutan, the Orchids of Bhutan - A review. Intn. J. Pharm. Life Sci. 3(4): 1590-1606.

Yonzone, R. 2015. Studies on the Orchid Flora of Darjeeling Himalaya. Ph.D. Thesis. University of North Bengal, Raja Rammohunpur, Siliguri, West Bengal, India.

Yonzone, R. 2017. Current Availability Status and Medicinal Uses of Anoectochilus roxburghii (Wall.) Lindl. (Orchidaceae) in Darjeeling Himalaya of West Bengal, India. Trends in Biosciences. 10(31): 6565 - 6568. 